Cell Research, (2001); 11(1):37-43

\title{
Hydrogen peroxide-induced changes in intracellular pH of guard cells precede stomatal closure
}

\author{
ZHANG Xiao ${ }^{1,2}, \mathrm{~F}_{\text {a }}$ Cai DONG ${ }^{1}$, Jun Feng GAO ${ }^{2}$, Chun Peng SONG ${ }^{1, *}$ \\ ${ }^{1}$ Department of Biology, Henan University, Kaifeng 475001, China \\ ${ }^{2}$ College of Life Sciences, Northwest Sci-Tech University of Agriculture and Forestry, Yangling 712100, \\ China
}

\begin{abstract}
Epidermal bioassay demonstrated that benzylamine, a membrane-permeable weak base, can mimick hydrogen peroxide $\left(\mathrm{H}_{2} \mathrm{O}_{2}\right)$ to induce stomatal closure, and butyric acid, a membrane-permeable weak acid, can partly abolish the $\mathrm{H}_{2} \mathrm{O}_{2}$-induced stomatal closure. Confocal $\mathrm{pH}$ mapping with the probe 5-(and-6)-carboxy seminaphthorhodafluor-1-acetoxymethylester (SNARF-1-AM) revealed that $\mathrm{H}_{2} \mathrm{O}_{2}$ leads to rapid changes in cytoplasmic and vacuolar $\mathrm{pH}$ in guard cells of Vicia faba L, i. e. alkalinization of cytoplasmic areas occur red in parallel with a decrease of the vacuolar $\mathrm{pH}$, and that butyric acid pretreatment can abolish alkalinization of cytoplasmic areas and acidification of vacuolar areas of guard cells challenged with $\mathrm{H}_{2} \mathrm{O}_{2}$. These results imply that the alkalinization of cytoplasm via efflux of cytosol protons into the vacuole in guard cells challenged with $\mathrm{H}_{2} \mathrm{O}_{2}$ is important at an early stage in the signal cascade leading to stomatal closure.
\end{abstract}

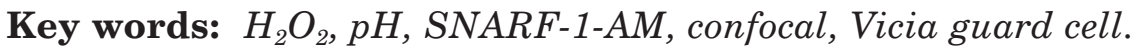

\section{INTRODUCTION}

Even under optimal conditions, many metabolic processes, including chloroplastic, mitochondrial, and plasma membrane-linked electron transport systems, produce reactive oxygen species (ROS) such as the superoxide radical $\left(\mathrm{O}_{2^{-}}\right)$, hydrogen peroxide $\left(\mathrm{H}_{2} \mathrm{O}_{2}\right)$, and the hydroxyl free radical $(\mathrm{OH}-)[1$, 2]. Furthermore, the imposition of biotic and abiotic stress conditions can give rise to excess concentrations of ROS, resulting in oxidative damage at the cellular level. Interestingly, ROS appear to play a crucial role in several metabolic processes of plants in a beneficial manner[3]. $\mathrm{H}_{2} \mathrm{O}_{2}$, in particular, have been previously implicated as a second messenger in plant cells exposed to environmental stresses such as chilling[4], heat[5], and pathogens $[6,7]$. The evidences that $\mathrm{O}_{2}$ - and $\mathrm{H}_{2} \mathrm{O}_{2}$ involved in

*Corresponding author:

E-mail: xzhangcn@china.com

Tel: 0378-2874021,2865799

Received Nov-9-2000 Reviced Jan-2-2001 Accepted Jan-31-2001 regulation of stomatal movement have been found [8], and also oxidative stress resulting from exposure to methyl viologen (which generates $\mathrm{O}_{2}$ radicals) or $\mathrm{H}_{2} \mathrm{O}_{2}$ has a marked effect on stomatal aperture[9], and exogenous $\mathrm{H}_{2} \mathrm{O}_{2}\left(\leqslant 10^{-5} \mathrm{M}\right)$ can induce stomatal closure and inhibit stomatal opening without any damage to cells[10]. Recent studies using recombinant aequorin techniques have demonstrated that $\mathrm{H}_{2} \mathrm{O}_{2}$ stimulates a transient increase in whole-plant calcium concentration $\left(\left[\mathrm{Ca}^{2+}\right]\right.$ i)in tobacco seedling[11]. In addition, ozone $\left(\mathrm{O}_{3}\right)$ has been shown to inhibit stomatal opening by inactivating the inward-rectifying $\mathrm{K}^{+}$channel in plasma membrane[12]. Moreover, our previous work using voltage clamp had demonstrated that externally applied $\mathrm{H}_{2} \mathrm{O}_{2}$ could induce stomatal closing by the inhibition of $\mathrm{K}^{+}$uptake and evoking $\mathrm{K}^{+}$ release through $\mathrm{K}^{+}$channels in plasma membrane of guard cells[13]. It has been widely confirmed that $\mathrm{H}_{2} \mathrm{O}_{2}$ regulates stomatal movement as a stress 
signal, yet there remain considerable gaps in our knowledge and in our attempts to construct a detailed description of the events and underlying signaling chains involved in the process of stomatal opening and closing.

Intracellular $\mathrm{pH}$ changes have long been proposed to function in signaling and transport control in plant cells, such as plant defense responses [14], tip growth [15], [16], nodulation[17], elicitation of benzophenanthridine alkaloids[18], and response to hormone activity such as gibberellic acid [19] and abscisic acid[20]. To date, cytoplasmic alkalinization is a major step in the ABA-triggered signal cascade in guard cells leading to $\mathrm{H}^{+}$efflux and stomatal closure[21], [22], and internal and external ABA can induce the generation of $\mathrm{H}_{2} \mathrm{O}_{2}$ in guard cells (manuscript to be submitted). However, up to now, no conclusive evidence has been provided concerning the earliest signals for stomatal closure by $\mathrm{H}_{2} \mathrm{O}_{2}$. Therefore, in the present paper we report dynamic changes of the intracellular $\mathrm{pH}$ distribution observed by confocal $\mathrm{pH}$ topography in guard cells challenged with $\mathrm{H}_{2} \mathrm{O}_{2}$.

\section{MATERIALS AND METHODS}

\section{Chemicals and reagents}

SNARF-1-AM was purchased from Molecular Probes (Eugene, OR). Nigericin, benzylamine and butyric acid were from Sigma. Dimethyl sulfoxide (DMSO) was from Amresco. Pluronic F-127 was from Bio-Rad. Unless stated otherwise, other chemicals were of analytical grade.

\section{Plant material}

Broad bean (Vicia faba L.) was grown from seed in pots with culture soil (nutrient soil/ vermiculite $2: 1$ ). The plants were kept in a greenhouse with a humidity of about $70 \%$, a photon flux density of 0.20 to $0.30 \mathrm{mmol} \mathrm{m} \mathrm{m}^{-2} \mathrm{~s}^{-1}$ and day/night temperature of $25 \pm 2{ }^{\circ} \mathrm{C} / 20 \pm 2{ }^{\circ} \mathrm{C}$. There were no stresses on plants during growing period.

\section{Epidermal strip bioassay}

Stomatal bioassay experiments were performed as described by McAinsh et.al.[10] with slight modifications. Immediately prior to each experiment, the epidermis was peeled carefully from the abaxial surface of the youngest and fully expanded leaves of 4-week-old plants, and cut into pieces of 5-mm length. To study promotion of stomatal closure by $\mathrm{H}_{2} \mathrm{O}_{2}$, freshly prepared abaxial epidermis was first incubated in $\mathrm{CO}_{2}$-free $50 \mathrm{mM}$ $\mathrm{KCl} / 10 \mathrm{mM}$ Mes, pH 6.15 (Mes-KCl) for $3 \mathrm{~h}$ under conditions promoting stomatal opening (at $22{ }^{\circ} \mathrm{C}$ to $25^{\circ} \mathrm{C}$, under a photon flux density of 0.20 to $0.30 \mathrm{mM} \mathrm{m}^{-2} \mathrm{~s}^{-1}$ ) to open the stomata, and then transferred to $\mathrm{CO}_{2}$-free Mes- $\mathrm{KCl}$ in the presence of $\mathrm{H}_{2} \mathrm{O}_{2}(10$ -
$5 \mathrm{M})$ or benzylamine $(10 \mathrm{mM})$ or butyrate $(10 \mathrm{mM})$ for $2 \mathrm{~h}$ under opening conditions, and stomatal apertures were determined microscopically at 30 -min intervals. Values are the means of 120 measurements \pm SE values.

\section{Loading with SNARF-1-AM}

The uncharged SNARF-1-AM can passively diffuse across the plasma membrane to cytosol, where it is hydrolyzed by cellular esterases to free SNARF-1. It is this form which is fluorescent, and is consequently the $\mathrm{pH}$ probe. The epidermal strips, which were first incubated for $3 \mathrm{~h}$ under conditions promoting stomatal opening, were placed in a small Petri dish containing $1 \mathrm{ml}$ $\mathrm{CO}_{2}$-free Mes-KCl buffer ( $\mathrm{pH}$ 6.15), with $20 \mu \mathrm{M}$ SNARF-1-AM from a $3 \mathrm{mM}$ stock solution in DMSO, and were incubated for 30 min in the dark at $25-27^{\circ} \mathrm{C}$. The fluorescence probe uptake was further facilitated when $0.05 \%$ pluronic F-127 was present. Loading was terminated by rinsing the strips several times in dyefree incubation buffer.

\section{Confocal pH topography}

Intracellular $\mathrm{pH}$ measurement and $\mathrm{pH}$ calibration using single excitation-dual emission fluorescence ratios were performed according to the method developed by Roos et al[18], [23]. Briefly, a confocal laser scanning microscope (Bio-Rad MicroRadiance) was used in dual-channel mode. Wavelength settings for SNARF-1 were $\mathrm{Ex}=488 \mathrm{~nm}$; Em=580nm (channel 1) and $\mathrm{Em}>600 \mathrm{~nm}$ (channel 2). Images were obtained with a Nikon TE300 inverted microscope (objective $40 \times / 0.60$ Plan Fluor). Signals from selected frames were scanned simultaneously in both channels and the intensity ratio (channel 1 : channel 2) was calculated for each pixel. $\mathrm{pH}$ maps were obtained by color coding these intensity ratios according to self-defined look-up tables, as supplied by the manufacturer. To enable the comparison of changes in signal intensity, confocal images were taken using identical exposure conditions (in manual setup) for all samples. Experiments were repeated at least three times with reproducible results, and the selected confocal image was the representative of about eight pictures.

The measured intensity ratios were converted to $\mathrm{pH}$ by means of a calibration graph. For this purpose, SNARF-preloaded epidermal strips were incubated in Mes buffers, $\mathrm{pH}$ 5.5-7.5 (adjusted with Tris), containing $50 \mathrm{mM} \mathrm{KCl,} 10 \mathrm{mM}$ Mes, $10 \mu \mathrm{M}$ butyrate, $10 \mathrm{mM}$ nigericin $\left(\mathrm{a} \mathrm{K}^{+} / \mathrm{H}^{+}\right.$exchanger which results in a equilibration of external and internal $\mathrm{pH}$ ), for another $20 \mathrm{~min}$, then the ratio-versus-pH curve were obtained by scanning $\mathrm{pH}$ maps of above cells and averaging to yield fluorescence ratios at defined $\mathrm{pH}$ values (Fig 1). Changes in intracellular $\mathrm{pH}$ can be calculated as a linear relationship between $\mathrm{pH}$ and fluorescence intensity ratios over the $\mathrm{pH}$ ranges 5.5-7.5.

\section{RESULTS}

Changes in stomatal behavior in response to $\mathrm{H}_{2} \mathrm{O}_{2}$, benzylamine and butyric acid

To determine whether an intracellular $\mathrm{pH}$ change is involved in stomatal closure by $\mathrm{H}_{2} \mathrm{O}_{2}$, we 
measured the effects of weak base (benzylamine) and acid (butyric acid) on stomatal movement. As shown in Fig 2 and Fig 3, $10 \mathrm{mM}$ benzylamine, similar to $10^{-5} \mathrm{M} \mathrm{H}_{2} \mathrm{O}_{2}$, induced stomatal closure, and $10 \mathrm{mM}$ butyric acid partly abolished the $\mathrm{H}_{2} \mathrm{O}_{2}$ induced stomatal closure. However, treatment with $10 \mathrm{mM}$ butyric acid alone induced a slight stomatal opening over untreated controls. These indicated that guard cell alkalinization occurred in response to $\mathrm{H}_{2} \mathrm{O}_{2}$, and cytosolic alkalinization was possibly an "upstream" factor of stomatal closure induced by $\mathrm{H} 2 \mathrm{O} 2$.

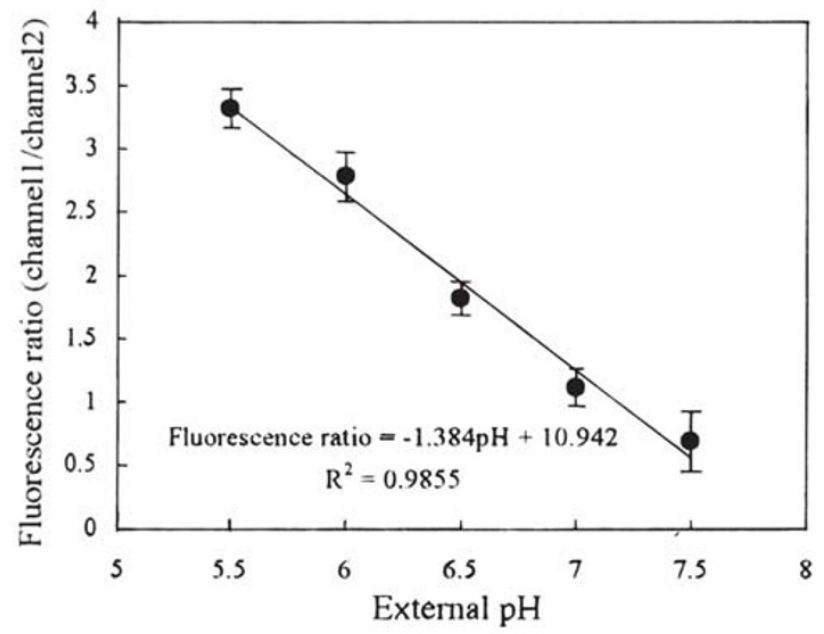

Fig 1. Calibration of pH-dependent fluorescence of carboxy SNARF-1. Fluorescence intensity ratios are averaged from at least 5 values, each representing the mean intensity ratio of an area over the whole guard cell tested.

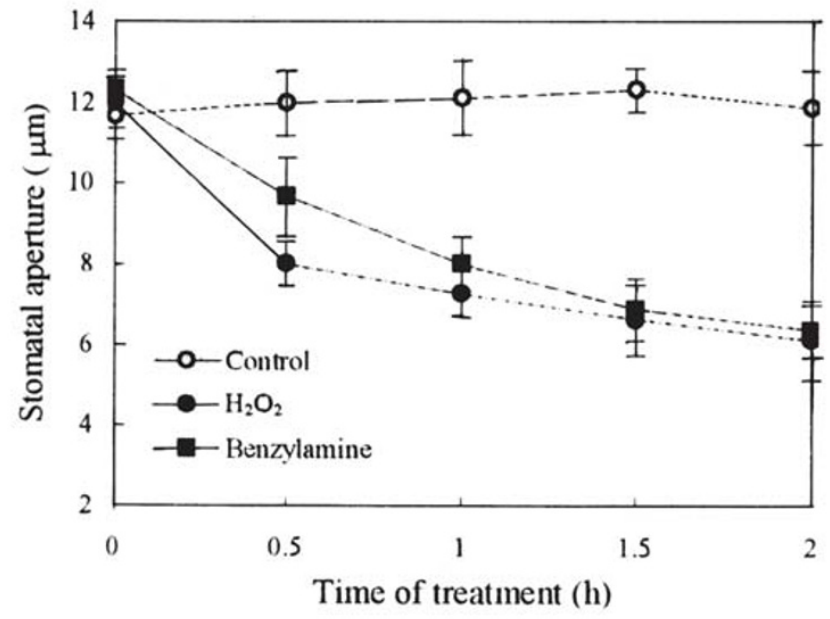

Fig 2. Effect of benzylamine (10 $\mathrm{mM})$ and H2O2 (10-5 M) on the stomatal closure.
$\mathrm{H}_{2} \mathrm{O}_{2}$-induced changes in intracellular $\mathrm{pH}$ of guard cells

Having established that cytosolic alkalinization was involved in the regulation of stomatal closure induced by $\mathrm{H}_{2} \mathrm{O}_{2}$ in above epidermal strips bioassay experiments, we then considered whether external $\mathrm{H}_{2} \mathrm{O}_{2}$ induces changes in intracellular $\mathrm{pH}$ of guard cells or not. In this study, subcellular regions were delineated by using bright-field and $\mathrm{pH}$-sensitive fluorescence ratio analysis to determine which cellular compartments had undergone changes in fluorescence intensity. Time-course quantitative analysis was performed in the cytosol (area 1, 3, 5) and the vacuole (area 2, 4). As shown in Fig 4, the mean $\mathrm{pHs}$ of the cytoplasmic and vacuolar areas stayed about 7.0 and 5.9 respectively in guard cell without treatment (Fig $4 \mathrm{D}$ ). After adding $10^{-5} \mathrm{M}$ $\mathrm{H}_{2} \mathrm{O}_{2}$, the mean cytoplasmic $\mathrm{pH}$ increased by around 0.3 unit in parallel with the mean vacuolar $\mathrm{pH}$ decreasing by around 0.4 unit (Fig 4 H, Fig 4 I). Following $\mathrm{H} 2 \mathrm{O} 2$ treatment, an increase in intracellular $\mathrm{pH}$ also occurred in the surrounding epidermal cells (decreasing background fluorescence ratio as in Fig 4), which is in accordance with the effect of ABA on stomatal closure[24].

Effects of butyric acid on changes in intracellular $\mathrm{pH}$ of guard cells induced by $\mathrm{H}_{2} \mathrm{O}_{2}$

The data presented above raise the question of whether an increase of the cytoplasmic $\mathrm{pH}$ alone is sufficient to produce a signal for the induction of stomatal closure. By using a 10 min treatment with

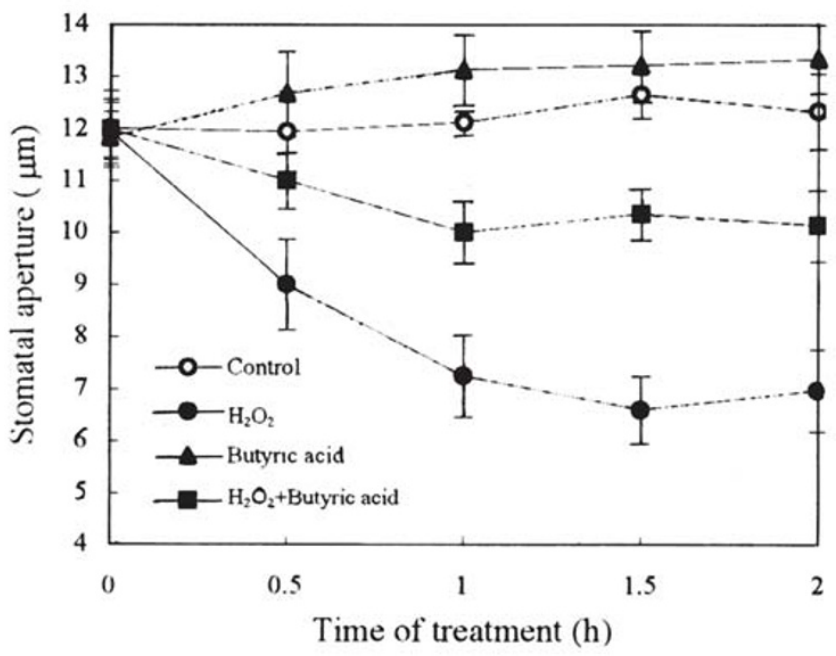

Fig 3. M Effect of butyric acid (10 $\mathrm{mM})$ on the promotion of stomatal closure by $\mathrm{H}_{2} \mathrm{O}_{2}$. 
butyric acid (a membrane-permeable weak acid that has frequently been used to decrease the intracellular $\mathrm{pH}$ of various cell types in experiments [14], [25]), we were able to evoke an acidification of the cytoplasm. As shown in Fig 5, butyric acid (in Mes-KCl buffer with $\mathrm{pH}$ adjusted to 6.15) pretreatment lowered significantly the intracellular $\mathrm{pH}$ in both cytoplasmic and vacuolar areas, especially the latter (compare the $\mathrm{pH}$ maps $\mathrm{D}$ in Fig 4 and Fig 5 at zero $\min$ before the addition of $\mathrm{H}_{2} \mathrm{O}_{2}$ ). With the prolongation of $\mathrm{H}_{2} \mathrm{O}_{2}$ treatment, the mean cytoplasmic $\mathrm{pH}$ stayed around 6.8 and that of vacuolar $\mathrm{pH}$ showed no drop but a slight increase (compare Fig 5 G with Fig 4 I), both indicating that butyric treatment can abolish partly the cytosolic alkalin- ization induced by $\mathrm{H}_{2} \mathrm{O}_{2}$.

\section{DISCUSSION}

Despite the recognition of $\mathrm{H}_{2} \mathrm{O}_{2}$ as a central signaling molecule in stress and wounding responses, pathogen defense, and regulation of cell cycle and cell death, little is known about how the signal is perceived and transduced in plant cells. Previous studies have unraveled that $\mathrm{H}_{2} \mathrm{O}_{2}$, similar to ABA, regulates stomatal movement via an increase in $\left[\mathrm{Ca}^{2+}\right] i$ as a second messenger $[10,11]$. Intracellular $\mathrm{pH}$ regulation is a characteristic and necessary feature of all living cells. There is increasing evidences that suggest changes in intracellular $\mathrm{pH}$ can act as a second messenger in plants[14,26,
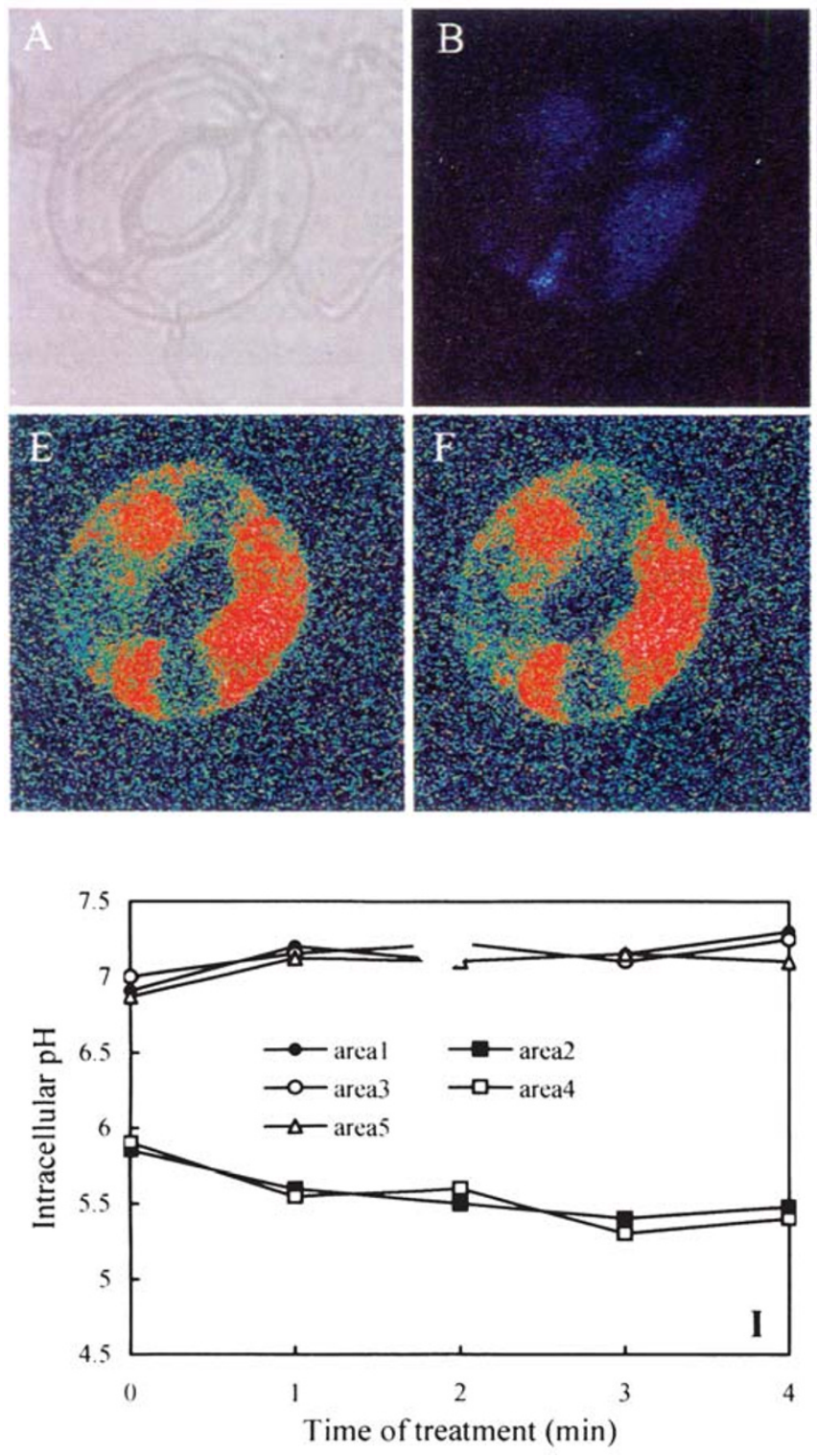
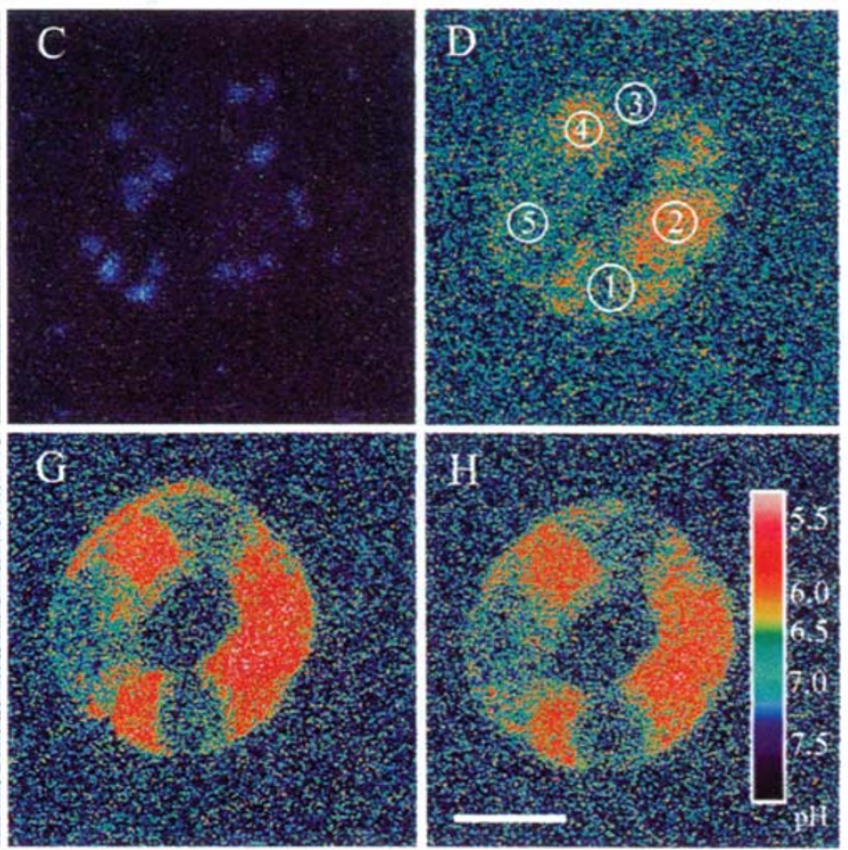

Fig 4. pH distribution of an open stomata of broad bean guard cells after the addition of $10^{-5} \mathrm{M} \mathrm{H}_{2} \mathrm{O}_{2}$. Photograph $\mathrm{A}$ is the transmission light image. Photographs $\mathrm{B}$ and $\mathrm{C}$ are the fluorescence intensity images acquired from channel 1 (Em $580 \mathrm{~nm}$ ) and channel $2(\mathrm{Em}>600 \mathrm{~nm})$ respectively at $0 \mathrm{~min}$ before the addition of $\mathrm{H}_{2} \mathrm{O}_{2}$. Photograph $\mathrm{D}$ is a $\mathrm{pH}$ map derived by ratioing the image intensities (channel 1/channel 2) at 0 min before the addition of $\mathrm{H}_{2} \mathrm{O}_{2}$; circles point to analyzed areas with vacuoles $(2,4)$ and cytoplasm $(1,3,5)$. Photograph E, F, G, H are pH maps derived by ratioing the image intensities (channel $1 /$ channel 2 ) at 1 min, $2 \mathrm{~min}, 3 \mathrm{~min}$ and $4 \mathrm{~min}$ after the addition of $\mathrm{H}_{2} \mathrm{O}_{2}$ respectively. Fig I is the time-course plot of fluorescence ratios of selected areas in photograph $\mathrm{D}$. The pseudocolor bar in photograph $\mathrm{H}$ represents a $\mathrm{pH}$ range from about 5.5 in vacuolar area to 7.5 in cytoplasmic area. $\operatorname{Bar}=10 \mu \mathrm{m}$. 

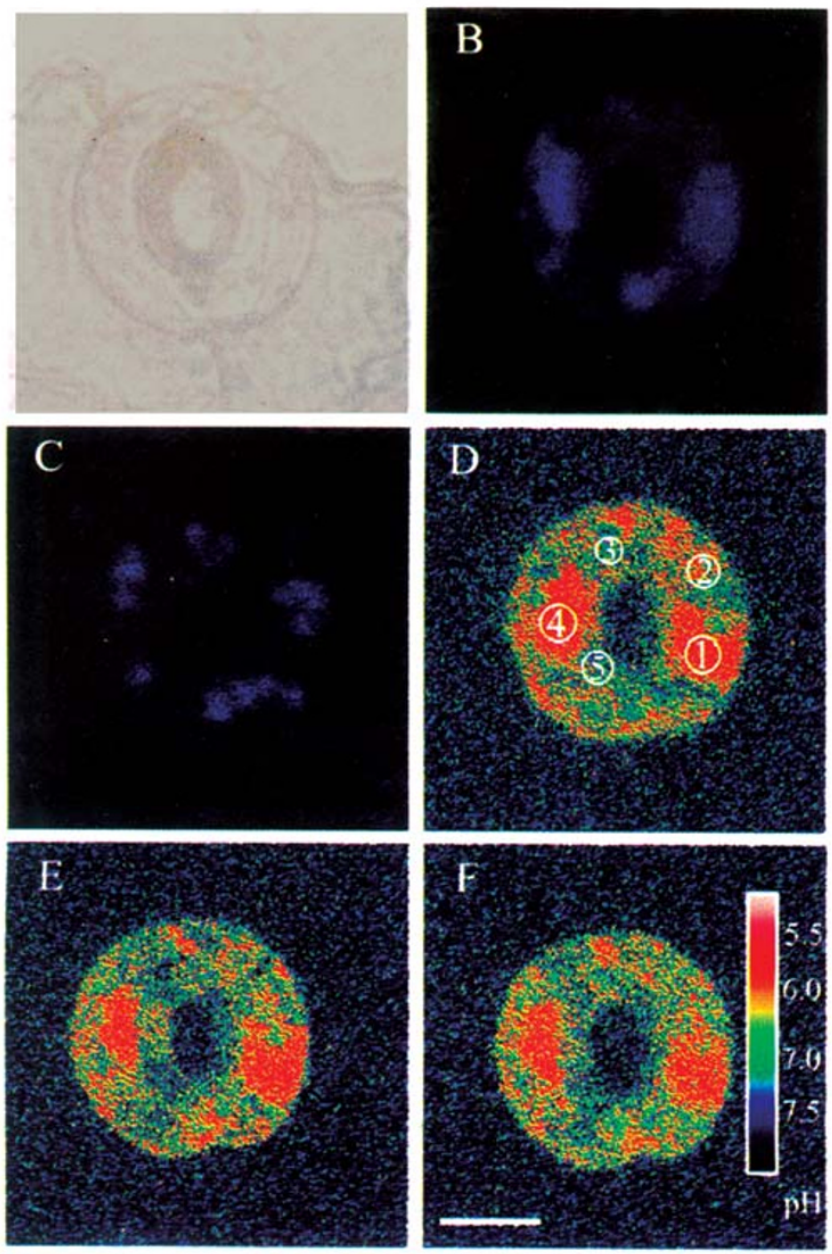

27]. Unlike intracellular free $\mathrm{Ca}^{2+}$ concentrations, which can rapidly change by perhaps 100 -fold, the $\mathrm{pH}$ inside a cell varies by only fractions of a $\mathrm{pH}$ unit, but even with such small change, it still exerts many physiological roles[15].

The data presented here, for the firsttime as far as our knowledge, is concerned that intracellular $\mathrm{pH}$ changes are involved in $\mathrm{H}_{2} \mathrm{O}_{2}$-induced stomatal closure. Epidermal strip bioassay has shown that the cytoplasmic alkalinization possibly mediated $\mathrm{H}_{2} \mathrm{O}_{2}$-induced stomatal closure (Fig 2, Fig 3), which is similar to results seen in guard cells in response to $\mathrm{ABA}[21,24]$. To provide further evidence for the specific involvement of cytoplasmic alkalinization in $\mathrm{H}_{2} \mathrm{O}_{2}$ signaling leading to stomatal closure and to investigate the shifts of intracellular $\mathrm{pH}$ distribution, we used $\mathrm{pH}$-sensitive SNARF-1$\mathrm{AM}$ to directly measure the fast intracellular $\mathrm{pH}$ changes. SNARF-1 enters cells in the diacetate form (SNARF-1-AM), and is then hydrolyzed by cellular

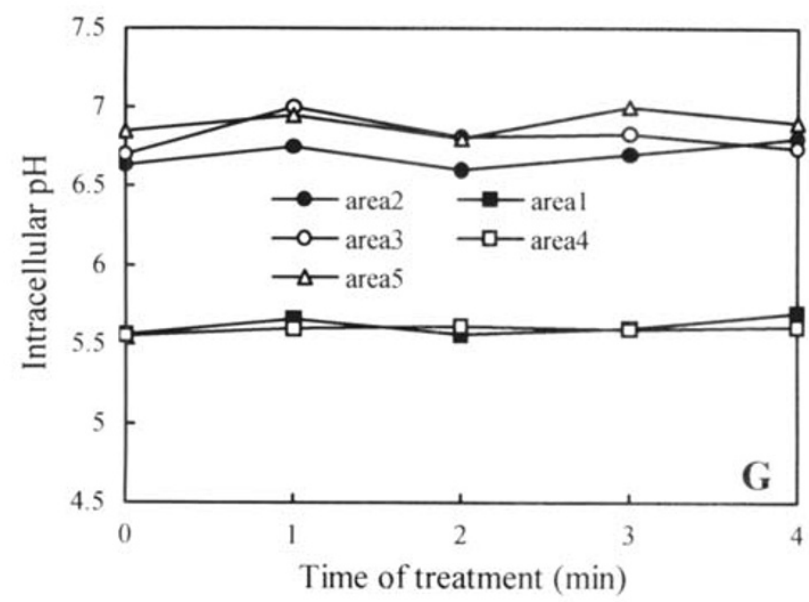

Fig 5. Effects of 10 min pretreatment with butyric acid on changes of intracellular $\mathrm{pH}$ in guard cells challenged with $1^{-5} \mathrm{M} \mathrm{H}_{2} \mathrm{O}_{2}$. Prior to experiment, SNARF-1-loaded epidermis were incubated in Mes-KCl buffer containing $10 \mathrm{~m} \mathrm{M}$ butyric acid for $10 \mathrm{~min}$. Photograph $\mathrm{A}$ is the transmission light image. Photographs $\mathrm{B}$ and $\mathrm{C}$ are the fluorescence image intensities acquired from channel $1(E m 580 \mathrm{~nm})$ and channel $2(E m>600 \mathrm{~nm})$ respectively at 0 min before the addition of $\mathrm{H}_{2} \mathrm{O}_{2}$. Photograph $\mathrm{D}$ is a $\mathrm{pH}$ map derived by ratioing the image intensities (channel 1/channel 2) at 0 min before the addition of $\mathrm{H}_{2} \mathrm{O}_{2}$; circles point to analyzed areas with vacuoles $(1,4)$ and cytoplasm $(2,3,5)$. Photographs $\mathrm{E}, \mathrm{F}$, are $\mathrm{pH}$ maps derived by ratioing the image intensities (channel 1/channel 2) at $1 \mathrm{~min}, 4 \mathrm{~min}$ after the addition of $\mathrm{H}_{2} \mathrm{O}_{2}$ respectively. Fig $\mathrm{G}$ is the timecourse plot of fluorescence ratios of selected areas in photograph D. The pseudocolor bar in photograph $\mathrm{F}$ represents a $\mathrm{pH}$ range from about 5.5 to 7.5 as in Fig 4, Bar $=10 \mu \mathrm{m}$.

esterases and trapped as SNARF-1, which is a single-excitation dual-emission fluorescent probe and its optical properties make it amenable to ratiometric imaging by confocal laser scanning microscopy to measure quantitatively intracellular $\mathrm{pH}$ changes. Additionally, ratiometric measurements reduce or eliminate variations of several determining factors in measuring fluorescence intensity, including indicator (dye or probe) concentration, excitation pathlength, excitation intensity and detection efficiency, and many artifacts are also eliminated including photobleaching and leakage of the indicator, variable cell thinkness, and nonuniform indicator distribution within cells (due to compartmentalization). A single cell assay illustrated that $\mathrm{H}_{2} \mathrm{O}_{2}$ induces rapid changes in cytoplasmic and vacuolar $\mathrm{pH}$ in guard cells of Vicia faba, i.e. alkalinization of cytoplasmic areas occurred in parallel with a decrease of the vacuolar $\mathrm{pH}$, and that butyric acid 
pretreatment partly abolished alkalinization of cytoplasmic areas and acidification of vacuolar areas of guard cells challenged with $\mathrm{H}_{2} \mathrm{O}_{2}$ (Fig 4 and Fig 5 ), which are coincident with the epidermal bioassay (Fig 2 and Fig 3). These results imply that the alkalinization of the cytosol may be accomplished via a $\mathrm{H}^{+}$efflux from cytosol to vacuole through vacuolar $\mathrm{H}^{+}$-ATPase. Proton gradient across tonoplast is possible a necessary factor in $\mathrm{H}_{2} \mathrm{O}_{2}$-induced stomatal closure.

In addition, ratiometric fluorescence of the edges of guard cell challenged with $\mathrm{H}_{2} \mathrm{O}_{2}$ is more significant than that in the same cell with $\mathrm{H}_{2} \mathrm{O}_{2}$-free treatment (Fig 4), and this implies that $\mathrm{H}_{2} \mathrm{O}_{2}$ possibly activates plasma membrane $\mathrm{H}^{+}$-ATPase, which will cause a more acidification of cell wall. In plant cells, plasma membrane $\mathrm{H}^{+}$-ATPase is primarily responsible for generating membrane potential $[28,29]$. Therefore, changes in membrane potential may cause or may be a reflection of changes in cytosolic $\mathrm{pH}$ that are involved in signaling leading to stomatal closure. Taken together with other recent data[10,12,13,21,24], we postulate that $\mathrm{H} 2 \mathrm{O} 2$ induced stomatal closure is probably mediated by the alkalinization of cytoplasm, intracellular $\mathrm{Ca}^{2+}$ increase and depolarization of plasma membrane leading to $\mathrm{K}^{+}$channel changes. However the spatiotemporal relationship between $\mathrm{pH}$ and $\mathrm{Ca}^{2+}$ as well as plasma membrane $\mathrm{K}^{+}$channel in $\mathrm{H}_{2} \mathrm{O}_{2}$ signaling leading to stomatal closure remains unknown.

\section{ACKNOWLEDGEMENT}

This work was supported by National Natural Science Foundation of China (No. 39870372) and Henan Natural Science Foundation (No. 994012300).

\section{REFERENCES}

[1] Foyer CH, Lelandais M, Kunert KJ. Photooxidative stress in plants. Plant Physiol 1994; 92:696-717.

[2] Asada K. The role of ascorbate peroxidase and monodehydroascorbate reductase in $\mathrm{H}_{2} \mathrm{O}_{2}$ scavenging in plants. In: Scandalios JG. ed. Oxidative Stress and the Molecular Biology of Antioxidant Defenses. Cold Spring Harbor Laboratory Press: Cold Spring Harbor, NY. 1997: 715-35.

[3] Inze D, Van Montagu M. Oxidative stress in plants. Curr Opin Biotechnol 1995; 6:153-8.
[4] Prasad TK, Anderson MD, Martin BA, Stewart CR. Evidence for chilling-induced oxidative stress in maize seedings and a regulatory role for hydrogen peroxide. Plant Cell 1994; 6:65-74.

[5] Dat JF, Lopez-Dalgado H, Foyer CH, Scott IM. Parallel changes in $\mathrm{H}_{2} \mathrm{O}_{2}$ and catalase during thermotolerance induced by salicylic acid or heat acclimation in mustard seedlings. Plant Physiol 1998; 116:1351-7.

[6] Levine A, Tenhaken R, Dixon RA, Lamb C. $\mathrm{H}_{2} \mathrm{O}_{2}$ from the oxidative burst orchestrates the plant hypersensitive disease resistance response. Cell 1994; 79:583-93.

[7] Alvarez ME, Pennell RI, Meijer PJ, Ishikawa A, Dixon RA, Lamb C. Reactive oxygen intermediates mediate a systemic signal network in the establishment of plant immunity. Cell 1998; 92:773-84.

[8] Purohit S, Kumar GP, Laloraya M. Involvement of superoxide radical in signal transdution regulation of stomatal movements. Biochem Biophys Res Comm 1994; 205:30-7.

[9] Price AH. A possible role for calcium in oxidative plant stress. Free Radical Res 1990; 10:345-9.

[10] McAinsh MR, Clayton H, Mansfield TA, Hetherington AM. Changes in stomatal behavior and cytosolic free calcium in response to oxidative stress. Plant Physiol 1996; 111:1031-42.

[11] Price AH, Taylor A, Ripley SJ, Griffiths A, Trewavas AJ, Knight MR. Oxidative signals in tobacco increase cytosolic calcium. Plant Cell 1994; 6:1301-10.

[12] Torsethaugen G, Pell EJ, Assmann SM. Ozone inhibits guard cell $\mathrm{K}+$ channels implicated in stomatal opening. Proc Natl Acad Sci USA 1999; 96:13577-82.

[13] An GY, Song CP, Zhang X, Jing YC, Yang DM, Huang MJ, Zhou PA, Wu CH. Effects of hydrogen peroxide on stomatal movement and $\mathrm{K}^{+}$channel on plasma membrane in Vicia faba guard cell. Acta Phytophysiol Sin 2000; 26:458-64.

[14] Guern J, Mathieu Y, Thomine S, Jouanneau JP, Beloeil JC. Plant cells counteract cytoplasmic $\mathrm{pH}$ changes but likely use these $\mathrm{pH}$ changes as secondary messages in signal perception. Curr Top Plant Biochem Physiol 1992; 11:249-69.

[15] Scott AC, Allen NS. Changes in cytosolic pH within Arabidopsis root columella cells play a key role in the early signaling pathway for root gravitropism. Plant Physiol 1999; 121:1291-8.

[16] Feijo JA, Sainhas J, Hackett GR, Kunkel JG, Hepler PK. Growing pollen tubes possess a constitutive alkaline band in the clear zone and a growth-dependent acidic tip. J Cell Biol 1999; 144:483-96.

[17] Felle HH, Kondorosi E, Kondorosi A, Schultze M. Rapid alkalinization in alfalfa root hairs in response to rhizobial lipochitooligosaccharide signals. Plant J 1996; 10:295301. [18] Roos W, Evers S, Hieke M, Tschope M, Schumann B. Shifts of intracellular $\mathrm{pH}$ distribution as a part of the signal mechanism leading to the elicitation of benzophenanthridine alkaloids. Plant Physiol 1998; 118:349-64.

[19] Swanson SJ, Jones RL. Gibberellic acid induces vacuolar acidification in barley aleurone. Plant Cell 1996; 8: 2211-21. 
[20] Beffagna N, Romai G, Meraviglia G, Pallini S. Effects of abscisic acid and cytoplasmic $\mathrm{pH}$ on potassium and chloride efflux in Arabidopsis thaliana seedlings. Plant Cell Physiol 1997; 38:503-10.

[21] Blatt MR, Armstrong F. $\mathrm{K}^{+}$channels of stomatal guard cells: abscisic-acid-evoked control of the outward rectifier mediated by cytoplasmic pH. Planta 1993; 191:33040.

[22] Assmann SM, Shimazaki KI. The multisensory guard cell. Stomatal responses to blue light and abscisic acid. Plant Physiol 1999; 119: 809-15.

[23] Roos W. Confocal pH topography in plant cells-acidic layers in the peripheral cytoplasm and the apoplast. Bot. Acta 1992; 105:253-9.

[24] Irving HR, Gehring CA, Parish RW. Changes in cytosolic $\mathrm{pH}$ and calcium of guard cells precede stomatal movements. Proc Natl Acad Sci USA 1992; 89:1790-4.

[25] Reid RJ, Smith FA, Whittington J. Control of intracellular $\mathrm{pH}$ in Chara corallina during uptake of weak acid. J Exp Bot 1989; 40:883-91.

[26] Felle H. pH as a second messenger in plants. In: Boss WF, Morre DJ. eds. Second messengers in plant growth and development. Alan R. Liss, NY. 1989:145-66.

[27] Zimmermann S, Ehrhardt T, Plesch G, Muller-Rober B. Ion channels in plant signaling. Cell Mol Life Sci 1999; 55:183-203.

[28] Briskin DP. $\mathrm{Ca}^{2+}$-translocating ATPase of the plasma membrane. Plant Physiol 1990; 94:397-400.

[29] Assmann SM, Haubrick LL. Transport proteins of the plant plasma membrane. Curr Opin Cell Biol 1996; 8: 458-67. 